\title{
Caso de Ensino: A Alocação de Custos Conjuntos em Processos com Múltiplos Pontos de Separação na Refinaria Fluminense S. A.
}

\section{Resumo}

O caso da Refinaria Fluminense S. A. tem por objetivo ilustrar a operação de uma refinaria de petróleo e os desafios que contadores e administradores enfrentam para apurar os custos dos derivados do petróleo, avaliar estoques, apurar o resultado das operações das refinarias e analisar decisões de continuar processando produtos individuais para aumentar seu valor agregado. Ele foi concebido para ser discutido nas disciplinas de Contabilidade Gerencial ou de Custos nos cursos de graduação e de pós-graduação em Ciências Contábeis, Administração e Engenharia de Produção. A narrativa tem início com a informação de que os acionistas estão exigindo que a administração tome providências para aumentar a rentabilidade da empresa. Ao analisar a rentabilidade dos produtos fabricados e comercializados, os administradores se dão conta de que não compreendem suficientemente bem a distribuição e o comportamento dos custos dos produtos. Convencidos da importância dessas informações, os administradores decidem contratar um especialista em custos, que promete sanar suas dúvidas e ajudá-los a analisar as decisões que terão que tomar para atender aos anseios dos acionistas. Pede-se, então, que os alunos assumam o papel do especialista e desenvolvam as questões propostas. Uma das mais relevantes contribuições do caso é que ele proporciona a oportunidade para os alunos confrontarem as exposições estilizadas dos livros-textos com as condições encontradas nas empresas. Isso se dá, especificamente, no caso da aplicação do método do valor realizável líquido em processos com múltiplos pontos de separação, um caso raramente comentado na grande maioria dos livros.

Palavras-chave: Processos de produção conjunta. Alocação de custos conjuntos. Múltiplos pontos de separação. Refinarias de petróleo.

\section{Raphael da Fonseca Graduado em Ciências Contábeis pela Universidade do Estado do Rio de Janeiro (UERJ) e Mestrando em Ciências Contábeis pela Universidade Federal do Rio de Janeiro (UFRJ). Contato: Av. Pasteur, 250, Sala 251, Urca, Rio de Janeiro/RJ, CEP: 22.290-240. \\ E-mail: raphafonseca@hotmail.com}

Moacir Sancovschi
Doutor em Administração pela
Universidade Federal do Rio de
Janeiro (UFRJ) e Professor na
Universidade Federal do Rio de
Janeiro (UFRJ). Contato: Av. Pasteur,
250, Sala 251, Urca, Rio de Janeiro/
RJ, CEP: 22.290-240.
E-mail: msancov@facc.ufrj.br




\section{Introdução}

O objetivo do caso da Refinaria Fluminense S.A. é ilustrar, de forma bastante simplificada, a operação de uma refinaria de petróleo e os desafios que contadores e administradores têm que enfrentar para apurar os custos dos derivados do petróleo, usar esses custos para determinar os custos dos estoques e o resultado das operações e analisar decisões de continuar processando produtos individuais para aumentar seu valor agregado.

O parque de refino descrito foi inspirado na Refinaria de Paulínia (REPLAN), a maior refinaria do Brasil, pertencente à Petróleo Brasileiro S.A. - Petrobras. A empresa hipotética é apresentada como uma refinaria de 43 anos na qual o processo produtivo flui adequadamente. No entanto, sua atividade administrativa se limita ao mínimo essencial ao seu funcionamento.

Neste contexto, dois fatores "perturbam" o status quo da companhia: a exigência dos acionistas de aumento da rentabilidade do negócio e a possibilidade de imposição, sinalizada por parte das autoridades governamentais competentes, da redução dos níveis de emissão de poluentes do diesel.

Diante deste cenário, os administradores percebem que precisam rever os produtos comercializados pela Refinaria e controlar seus custos. No entanto, como é de se supor, eles se deparam com as dificuldades características de operações que envolvem custos conjuntos, tais como, um processo produtivo com quatro pontos de separação e produtos intermediários que não são comercializados regularmente, e, portanto, não têm preços de mercado.

Conscientes da importância dessas informações, mesmo sem compreendê-las adequadamente, os gestores decidem contratar um especialista em custos, que promete sanar suas dúvidas e ajudá-los a analisar as decisões que terão que tomar. Pede-se, então, que os alunos assumam o papel do especialista e desenvolvam as questões propostas. Os personagens e a conjuntura retratados buscam propiciar uma referência com a realidade encontrada nas empresas, pretendendo sair do plano meramente teórico e de soluções simplificadas e automáticas.

Desta forma, buscou-se demonstrar, ao longo do caso, que o tema pode ser abordado por diversos ângulos e com diferentes níveis de complexidade, proporcionando não apenas a realização dos cálculos, mas, principalmente, a reflexão acerca da utilidade da informação produzida, das vantagens e desvantagens da aplicação dos diferentes métodos de alocação de custos, e dos conceitos envolvidos. O caso proporciona ainda discussões relativas à relevância da informação contábil e à utilização de custos para formação de preços, complementando, portanto, o conteúdo dos capítulos dos livros de contabilidade de custos e contabilidade gerencial que tratam de custos de produtos conjuntos e de subprodutos. Como eles geralmente utilizam exemplos de processos de produção excessivamente ingênuos nas exposições e nos exercícios, subestimando as complexidades de fato encontradas nas empresas, o caso da Refinaria Fluminense S.A. permite que os alunos experimentem uma situação mais próxima da realidade, de forma controlada.

Um dos aspectos mais relevantes deste trabalho é que o processo de produção da refinaria em questão tem múltiplos prontos de separação, um problema raramente mencionado nos livros de contabilidade (Horngren \& Foster, 1987; e Lowenthal, 1986), e que exige alguns cuidados, especialmente na distribuição dos custos conjuntos através do método do valor realizável líquido.

\section{A Refinaria}

A Refinaria Fluminense S.A. foi fundada em 1973 e está localizada na cidade do Rio de Janeiro. Em 1995, a capacidade de processamento de seu parque de refino foi ampliada de $45 \mathrm{mil} \mathrm{m}^{3}$ / dia para $66 \mathrm{mil}$ $\mathrm{m}^{3}$ / dia de petróleo, que equivalem a 415 mil barris de petróleo por dia. A alta administração da refinaria é integrada por Antônio Dantas, o atual presidente, por Carlos Mendes, diretor de operações, e por Fernando Gonçalves, diretor de administração. O número de funcionários administrativos é bastante pequeno, mas todos são muito qualificados, refletindo o foco da empresa na excelência das atividades operacionais. 
Não obstante o compromisso da alta administração com a eficiência das operações, os acionistas da companhia estão reclamando, há algum tempo, que a rentabilidade do negócio está inferior às suas expectativas. Para agravar a situação, recentemente as autoridades governamentais começaram a sinalizar a possibilidade de impor uma redução nos níveis de emissão de poluentes do diesel de 500 partículas de enxofre por milhão para 50 partículas de enxofre por milhão, o que necessariamente demandará mudanças nos processos de fabricação, acarretando, consequentemente, aumento nos custos de produção.

Preocupado com as pressões dos acionistas e com as consequências das prováveis exigências das autoridades, Dantas decidiu se reunir com Mendes e com Gonçalves no dia 3 de janeiro de 2017, pela manhã, para examinar os problemas e definir como eles poderiam ser enfrentados.

\section{A Reunião}

Assim que Dantas mostrou a todos a gravidade dos fatos e falou na premência de cortar custos, Gonçalves disse que sua equipe tinha sido reduzida há três meses, e que não poderia perder novos funcionários sem comprometer os resultados que todos esperavam das atividades administrativas.

Mendes, diretor de operações, fazendo coro com Gonçalves, destacou que sua equipe era qualificada e muito eficiente, e que cortes na área operacional poderiam reduzir a qualidade dos processos e aumentar os riscos das operações. Ele defendeu, específica e veementemente, a necessidade de se tomarem os devidos cuidados no processamento e na movimentação do petróleo e de seus derivados para proteger os funcionários, a comunidade vizinha à refinaria e o meio ambiente. Ressaltou ainda que, de acordo com o mais recente relatório de acompanhamento físico da produção, a refinaria processou, em dezembro de 2016, 12,5 milhões de barris de petróleo, ou seja, 403 mil barris/dia, o que indicava que ela estava utilizando $97 \%$ de sua capacidade instalada.

Depois de ouvir os diretores, Dantas disse: "Compreendo e concordo com vocês. Como estamos operando muito próximo de nossa capacidade instalada, não controlamos os preços dos derivados que produzimos e não temos como fazer novos cortes na área administrativa nem na área operacional, só nos resta estudar a fundo os custos de produção da refinaria, os produtos que estamos fabricando e as possibilidades de submetê-los a novos processos para agregar valor a eles".

Mendes, diretor de operações, afirmou que, para fazer estas análises, precisaria de informações financeiras confiáveis. Dantas perguntou, então, ao Gonçalves se o departamento de contabilidade gerava regularmente relatórios de custos e de rentabilidade por produto, e ele respondeu que não, mas que não seria difícil fornecer as informações que Mendes estava solicitando. Terminada a reunião, Gonçalves solicitou que o gerente da Contabilidade verificasse quais informações Mendes precisaria e tomasse as providências para fornecê-las em caráter prioritário.

\section{O Relatório de Rentabilidade por Produtos}

$\mathrm{Na}$ tarde do dia seguinte, o presidente recebeu uma cópia do relatório de rentabilidade por produtos referente ao mês de dezembro de 2016, que havia sido solicitado por Mendes, e ficou muito preocupado. Ele viu que dois produtos apresentavam prejuízo e, então, pediu explicações a Gonçalves. Mas o diretor de administração reconheceu, com certo desconforto, que precisaria examinar melhor a origem dos prejuízos identificados.

Gonçalves justificou ao presidente: "O Departamento de Contabilidade está com poucos funcionários e todos estão muito comprometidos em cumprir as obrigações tributárias e em preparar as demonstrações financeiras trimestrais e anuais. Essas atividades ocupam todo o tempo disponível, restringindo nossa capacidade de fornecer aos gerentes as informações e os esclarecimentos que eles precisam como seria desejável". 
Mendes advertiu a Dantas que cortar custos, indiscriminadamente, seria um perigo. Sugeriu, então, que seria melhor contratar um consultor especializado em custos para analisar as operações da refinaria e ajudar os gestores a avaliar as decisões que precisariam ser tomadas. O presidente concordou. E foi assim que Pedro Souza, um consultor especializado em custos, foi contratado. Sua missão era rever o sistema de custeio dos produtos e dar o suporte desejado pelos gerentes.

Pedro e a alta administração da empresa tiveram uma reunião de alinhamento de expectativas antes do início efetivo do serviço de consultoria.

Dantas deixou bem claro que, além da revisão do sistema de custeio, desejava uma avaliação de viabilidade econômica das seguintes possibilidades:

- Submeter o diesel e a gasolina a processamento adicional para obtenção de produtos de maior valor agregado;

- Atender, eventualmente, a pedidos de algumas indústrias petroquímicas interessadas em comprar pequenas quantidades (negócios marginais) de Nafta e de Nafta Craqueada.

O presidente externou, ainda, preocupação com a possibilidade da imposição, por parte das autoridades competentes, de redução nos níveis de emissão de poluentes do diesel, com consequentemente aumento nos custos de produção.

O consultor avisou aos administradores que estava familiarizado com os métodos de apuração e análise de custos de produtos conjuntos e de subprodutos, mas nunca tinha prestado serviços a uma refinaria de petróleo.

Como o profissional foi muito bem recomendado e tinha uma excelente reputação no mercado, Mendes e Gonçalves se prontificaram a colocar à sua disposição os melhores funcionários da contabilidade e da área operacional para que ele pudesse realizar um trabalho de alta qualidade, com a urgência requerida.

\section{A Produção dos Derivados de Petróleo}

Os funcionários indicados por Mendes e Gonçalves mostraram a Pedro a refinaria e explicaram a ele detalhadamente como o petróleo é processado para dar origem aos seus vários produtos derivados. A seguir, são apresentadas algumas anotações feitas por Pedro com base nas informações que lhe foram fornecidas.

A refinaria recebe petróleo bruto e o processa para obter Gás Liquefeito de Petróleo (GLP), Gasolina, Diesel, Querosene de Aviação (QAV), Óleo Combustível e Coque. A proporção de cada um desses derivados é determinada pelo tipo de petróleo que é processado e pelas características das instalações da refinaria.

Embora haja vários tipos de petróleo, que dão origem a proporções distintas de derivados e que proporcionam lucros esperados diferentes, a flexibilidade para escolher, dentre os tipos, aquele que em um momento promete lucro esperado superior aos demais é limitada pelo fato de cada refinaria ser projetada para aproveitar da melhor forma possível um tipo de petróleo. A Refinaria Fluminense S.A. foi concebida, especificamente, para processar petróleo brasileiro e maximizar, a partir dele, a produção de derivados mais nobres, como o diesel e a gasolina, e evitar a produção de óleo combustível e coque, de menor valor.

Para montar um diagrama de fluxo do processo de produção e poder apurar os custos de produção dos vários derivados do petróleo, Pedro reuniu as seguintes informações:

- O petróleo bruto chega à refinaria através de dutos e é armazenado em tanques. Dos tanques, ele é enviado à Unidade de Destilação Atmosférica, onde é aquecido para dar origem ao gás liquefeito de petróleo (GLP), à Nafta, à mistura Diesel/Querosene, e ao Resíduo atmosférico;

- O GLP, por estar pronto para a comercialização, é armazenado em esferas; 
- A Nafta é transferida para a Unidade de Hidrotratamento de Nafta, e daí para a Unidade de Reforma Catalítica onde é obtida a gasolina, que é armazenada em tanques por ser um produto final;

- A mistura Diesel/Querosene segue para a Unidade de Hidrotratamento de Diesel e Querosene, de onde saem dois produtos: o Diesel Hidrotratado e o Querosene de Aviação (QAV). Eles são, então, armazenados nos respectivos tanques, por serem produtos finais;

- O Resíduo Atmosférico é enviado à Unidade de Destilação à Vácuo onde são obtidos o Coque, o Óleo Combustível e o Gasóleo. O Coque é descarregado em caminhões para venda; o Óleo Combustível é armazenado em tanques; e o Gasóleo é transferido para a Unidade de Craqueamento Catalítico;

- Na Unidade de Craqueamento Catalítico são quebradas as cadeias de átomos do Gasóleo para obter o GLP, que é armazenado em tanques, o Diesel de Craqueamento Catalítico Fluido e a Nafta Craqueada;

- O Diesel de Craqueamento Catalítico Fluido é transferido para a Unidade de Hidrotratamento de Diesel e Querosene para dar origem ao Diesel e ao QAV;

- A Nafta Craqueada segue para a Unidade de Hidrodessulfurização de Nafta Craqueada, de onde se obtém gasolina, que é armazenada em tanques.

\section{Levantamentos Feitos nos Escritórios}

Após a visita ao parque de refino, Pedro foi aos escritórios, onde apurou as informações apresentadas nos Quadros 1 e 2, referentes às operações do mês de dezembro de 2016, quando foram processados 12.500 mil barris de petróleo bruto.

Quadro 1

Insumos e produtos por Unidade

\begin{tabular}{|c|c|c|c|c|}
\hline & Insumos (em milhar & de barris) & Produtos (em milha & de barris) \\
\hline \multirow{4}{*}{ Unidade de Destilação Atmosférica } & \multirow{4}{*}{ Petróleo } & \multirow{4}{*}{12.500} & GLP & 380 \\
\hline & & & Nafta & 1.800 \\
\hline & & & Diesel / Querosene & 5.350 \\
\hline & & & Resíduo Atmosférico & 4.970 \\
\hline $\begin{array}{l}\text { Unidade de Hidrotratamento de Nafta e de } \\
\text { Reforma Catalítica }\end{array}$ & Nafta & 1.800 & Gasolina & 1.800 \\
\hline \multirow{3}{*}{ Unidade de Destilação à Vácuo } & \multirow{3}{*}{ Resíduo Atmosférico } & \multirow{3}{*}{4.970} & Gasóleo & 3.410 \\
\hline & & & Coque & 760 \\
\hline & & & Óleo Combustível & 800 \\
\hline \multirow{3}{*}{ Unidade de Craqueamento Catalítico } & \multirow{3}{*}{ Gasóleo } & \multirow{3}{*}{3.410} & GLP & 275 \\
\hline & & & $\begin{array}{l}\text { Diesel de } \\
\text { Craqueamento } \\
\text { Catalítico Fluído }\end{array}$ & 2.400 \\
\hline & & & Nafta Craqueada & 735 \\
\hline \multirow[b]{2}{*}{$\begin{array}{l}\text { Unidade de Hidrotratamento de Diesel e } \\
\text { Querosene }\end{array}$} & Diesel / Querosene & 5.350 & Diesel Hidrotratado & 7.280 \\
\hline & $\begin{array}{l}\text { Diesel de } \\
\text { Craqueamento } \\
\text { Catalítico Fluído }\end{array}$ & 2.400 & QAV & 470 \\
\hline $\begin{array}{l}\text { Unidade de Hidrodessulfurização de Nafta } \\
\text { Craqueada }\end{array}$ & Nafta Craqueada & 735 & Gasolina & 735 \\
\hline
\end{tabular}

Fonte: os autores, 2016. 
Quadro 2

Preços praticados no mês de dezembro de 2016

\begin{tabular}{|c|c|}
\hline Produto & $\mathrm{R} \$ /$ barril \\
\hline Petróleo & 190,00 \\
\hline Gás Liquefeito de Petróleo (GLP) & 58,00 \\
\hline Gasolina & 270,00 \\
\hline Diesel & 236,70 \\
\hline Querosene de Aviação (QAV) & 228,00 \\
\hline Óleo Combustível & 160,00 \\
\hline Coque & 2,70 \\
\hline
\end{tabular}

Fonte: os autores, 2016

Pedro apurou os custos dos processos de refino, para o mês de dezembro de 2016, que estão registrados no Quadro 3; e que a refinaria incorre em despesas no valor de $\mathrm{R} \$ 52.000,00$ nas vendas de Coque.

Quadro 3

\section{Custos dos Processos de Refino}

\begin{tabular}{lllc}
\hline $\begin{array}{c}\text { Carga processada } \\
\text { (barris) }\end{array}$ & \multicolumn{1}{c}{ Unidade } & $\begin{array}{c}\text { Custos Fixos } \\
\text { (R\$) }\end{array}$ & $\begin{array}{c}\text { Custos Variáveis } \\
\text { (R\$/barril) }\end{array}$ \\
\hline 12.500 .000 & Destilação Atmosférica & 3.750 .000 & 0,50 \\
\hline 4.970 .000 & Destilação à Vácuo & 6.545 .000 & 1,50 \\
\hline 1.800 .000 & Hidrotratamento de Nafta & 1.600 .000 & 3,00 \\
\hline 1.800 .000 & Reforma Catalítica & 2.800 .000 & 4,00 \\
\hline 7.750 .000 & $\begin{array}{l}\text { Hidrotratamento de Diesel e } \\
\text { Querosene }\end{array}$ & 4.300 .000 & 2,00 \\
\hline 3.410 .000 & Craqueamento Catalítico & 3.950 .000 & 5,00 \\
\hline 735.000 & Hidrodessulfurização de & 1.325 .000 & 5,00 \\
\hline
\end{tabular}

Fonte: os autores, 2016

O contador informou a Pedro que os custos apresentados ao presidente no relatório do dia 4 de janeiro foram obtidos pela alocação dos custos conjuntos aos produtos principais por meio do método das unidades físicas. Informou ainda que não existiam estoques inicial nem final no mês de dezembro de 2016.

O consultor compilou os dados relativos à possibilidade de submeter a gasolina e o diesel a processos específicos para produzir a Gasolina e o Diesel Master. A expectativa é de que haverá boa aceitação no mercado para 1 milhão de barris de Gasolina Master e 2 milhões de barris de Diesel Master. Segundo levantamentos de mercado, a Gasolina Master poderá ser vendida por R $\$ 300$ o barril, enquanto o Diesel Master poderá ser vendido por $\mathrm{R} \$ 250 \mathrm{o}$ barril.

Pedro apurou que o custo esperado do processo de conversão da Gasolina em Gasolina Master seria de $\mathrm{R} \$ 10,00$ por barril, enquanto o custo esperado do processo de conversão do Diesel em Diesel Master seria de $\mathrm{R} \$ 9,00$ por barril. A área técnica da refinaria informou que em nenhum desses processos haveria qualquer ganho ou perda nas quantidades produzidas.

Quanto à possibilidade de, eventualmente, atender aos pedidos de algumas indústrias petroquímicas interessadas em comprar pequenas quantidades (negócios marginais) de Nafta e de Nafta Craqueada, segundo a área de vendas da refinaria, o preço esperado das ofertas é de $\mathrm{R} \$ 250,00$ por barril. De acordo com as estimativas do consultor, a redução da emissão das partículas de enxofre presentes no Diesel do nível atual de 500 para 50 partículas por milhão imporá à refinaria um custo incremental de $\mathrm{R} \$ 32,00$ por barril de diesel produzido. 
Concluído o levantamento, Pedro tinha algumas certezas, mas ainda precisava fazer algumas escolhas críticas que, certamente, teriam impacto relevante no relatório final que terá que preparar ao fim do projeto. A primeira certeza é que precisará representar esquematicamente o processo de produção da refinaria para não se perder no trabalho de apuração de custos. Porém, não está seguro sobre o método que deve recomendar para alocar os custos conjuntos. Resolveu, então, ouvir a opinião do contador da refinaria.

"Ainda não sei qual método de alocação dos custos conjuntos devo usar. Tanto o método das unidades físicas quanto o método do valor realizável líquido apresentam vantagens e desvantagens. Sabemos que o primeiro é simples e funciona em qualquer empresa, mas pode gerar resultados estranhos. Como alternativa, temos o segundo, que aloca os custos aos produtos com base na capacidade que eles têm de gerar receitas, mas é trabalhoso e difícil de implementar. Além disso, a refinaria possui múltiplos pontos de separação, caso raramente abordado nos livros tradicionais de custos, que complica a aplicação do método do valor realizável líquido. Fico me perguntando se os benefícios obtidos por uma alocação de custos mais equitativa compensarão os custos implementar e operacionalizar o método do valor realizável líquido. Por outro lado, ambos sabemos que a única utilidade dos custos unitários obtidos pela alocação dos custos conjuntos é determinar o custo dos estoques e apurar os resultados. Não há sentido em usar essas informações para analisar decisões. O que você pensa sobre tudo isso"?

Quando acabou de ouvir as considerações de Pedro, o contador sentiu que essa seria uma conversa demorada, e o convidou para tomar um café e fazer um lanche para tratarem destas questões com o cuidado que elas requeriam. Em relação aos demais pedidos do Dantas, o Pedro não via nenhum problema para atendê-los. Eram avaliações que dependiam de conceitos e de técnicas apresentados regularmente nos cursos e nos livros sobre os quais há um grande consenso.

Assuma o papel de Pedro, como consultor de custos, e analise as questões propostas a seguir.

\section{Questões}

Q1 - Assuma, como Pedro, que sem uma representação adequada do processo de refino será difícil fazer o trabalho de apuração dos custos dos produtos fabricados na Refinaria Fluminense S.A. Sendo assim, prepare um diagrama de fluxo que represente, de forma esquemática, o processo de produção da refinaria e determine as quantidades dos produtos obtidos no mês de dezembro de 2016.

Q2 - Classifique os derivados produzidos pela refinaria como produtos conjuntos principais ou subprodutos. Justifique sua classificação. Sabendo que existem vários métodos para o tratamento contábil dos subprodutos, escolha um método a ser aplicado no caso e defenda sua opção.

Q3 - Utilize o método das unidades físicas para apurar os custos dos produtos principais produzidos em dezembro de 2016. Com base nessas informações, determine o lucro bruto total e unitário dos produtos principais e dos subprodutos e o lucro da refinaria.

Q4 - Utilize o método do valor realizável líquido para apurar os custos dos produtos principais produzidos em dezembro de 2016. Com base nessas informações, determine o lucro bruto total e unitário dos produtos principais e dos subprodutos e o lucro da refinaria.

Q5 - Auxilie a administração a avaliar se há mérito em produzir e vender a Gasolina Master e o Diesel Master, justificando sua recomendação.

Q6 - Dê subsídios aos administradores para eles decidirem se devem aceitar as propostas de compra de Nafta e de Nafta Craqueada, pelas indústrias petroquímicas, embasando seu parecer. 
Q7 - Avalie o impacto do atendimento da exigência de redução do atual nível de emissão de partículas de enxofre presentes no diesel no resultado da Refinaria Fluminense S.A. Como a administração da refinaria deveria reagir a essa exigência? Seria possível atender a este anseio da sociedade sem repassar o acréscimo dos custos ao preço?

Q8 - Após todos os cálculos e avaliações realizados, Pedro ainda não tinha certeza de que método de alocação dos custos conjuntos deveria propor à administração da refinaria. Recomende a utilização de um dos métodos propostos nas questões 3 e 4 e justifique sua resposta, apresentando as vantagens e desvantagens do método que você julga ser o mais apropriado.

Q9 - Reflita acerca da utilidade e da relevância da informação contábil produzida com base no tratamento dos custos conjuntos. Como é possível tomar decisões baseadas em custos em um ambiente como o da Refinaria Fluminense S.A.?

\section{Notas de Ensino}

\subsection{Objetivos Educacionais}

O caso da Refinaria Fluminense S.A. foi concebido para levar os alunos a vivenciarem de forma controlada os problemas experimentados por contadores e administradores em uma empresa que opera um processo de decomposição. Eles terão a oportunidade de representar esquematicamente o processo de produção; identificar os produtos fabricados em cada etapa do processo de produção; classificá-los como produtos conjuntos e subprodutos; definir que valores serão atribuídos aos subprodutos; usar dois métodos distintos para alocar os custos conjuntos aos produtos conjuntos; e usar informações de custos para analisar decisões de processar adicionalmente alguns produtos, agregando valor a eles.

Como alguns dos produtos intermediários que dão origem aos produtos principais da Refinaria Fluminense S.A. não têm preços de mercado, uma das questões do caso pede que os alunos distribuam os custos conjuntos por meio do método do valor realizável líquido. Essa questão fará com que os alunos se deparem com múltiplos pontos de separação e descubram que essa possibilidade, em geral, não é cogitada nos livros de Contabilidade. Eles então terão a oportunidade de perceber que os múltiplos pontos de separação complicam, mas não impedem a aplicação do método do valor realizável líquido. Nesse aspecto, o caso demonstra que os problemas encontrados no cotidiano das empresas nem sempre são tão simples como fazem crer os capítulos que tratam de custos de produtos conjuntos e de subprodutos nos livros didáticos.

Kaplan (2007) denomina casos como o da Refinaria Fluminense S.A. de casos computacionais. Ele utiliza esses casos (por exemplo, Wilkerson Company e Sippican Corporation) para dar insights e confiança aos gerentes em relação aos conceitos e às técnicas que são empregadas para analisar ou responder as questões propostas. Não para treinar consultores ou líderes de projetos de desenvolvimento e implantação de sistemas de custos.

O caso da Refinaria Fluminense S.A. poderá ser aplicado nas aulas de Contabilidade de custos ou de Contabilidade gerencial nos cursos de graduação e de pós-graduação em Ciências Contábeis, Administração e Engenharia de Produção. 


\subsection{Arcabouço Teórico}

\subsubsection{Introdução}

A consulta aos livros escritos por Horngren (1972), Backer e Jacobsen (1974), Cashin e Polimeni (1981), Shillinglaw (1982), Horngren e Foster (1987), Horngren, Foster e Datar (2000), Hansen e Mowen (2001), Maher (2001), Martins (2003), Jiambalvo (2009), Horngren, Datar e Rajan (2012), e Horngren, Datar e Rajan (2015) mostra que os conceitos e técnicas de contabilidade para a análise e tratamento contábil dos custos de produtos conjuntos e de subprodutos estão consolidados há bastante tempo, e que nenhuma inovação significativa surgiu nessa área recentemente. Ela também evidencia que os capítulos sobre esse assunto são curtos porque são poucos os conceitos que precisam ser apresentados, e são simples as técnicas empregadas na determinação e na análise dos custos. Não obstante, este assunto merece ser tratado com certa deferência pelo fato de que ele desafia crenças fortemente arraigadas no imaginário e no discurso de contadores e de não contadores.

A primeira diz respeito à relevância das informações produzidas e reportadas pela Contabilidade. No caso dos produtos conjuntos e dos subprodutos, os custos alocados a eles só servem para determinar os custos dos estoques e apurar os resultados das empresas. Por não haver meios racionais para medir a contribuição dos diferentes fatores de produção para a fabricação dos diferentes produtos, a única forma de se apurarem os custos desses produtos é distribuir os custos de produção proporcionalmente entre os produtos.

Os modelos sugeridos e usados diferem somente nos fatores de proporcionalidade, mas não eliminam a arbitrariedade na alocação dos custos. Por isso, todos os autores acabam explicando que qualquer método que distribua todos os custos de produção a todos os produtos pode ser usado. Basta que se escolha um; que ele seja usado de forma consistente ao longo do tempo; e que ele seja devidamente explicitado nas notas explicativas que acompanham as demonstrações financeiras. Em seguida, os autores advertem que os custos alocados não devem ser usados para analisar decisões. Para algumas decisões, só interessam os custos de produção de todos os produtos e, para outras, somente os custos do último processo.

A segunda crença que é contrariada no caso de produtos conjuntos e de subprodutos é de que é preciso conhecer os custos de produção de um produto para determinar o seu preço. Como há diferentes métodos igualmente aceitáveis para se determinar os custos de produção dos produtos conjuntos e dos subprodutos, e cada um desses métodos gera números diferentes que não são explicados pelos fatores utilizados na fabricação dos produtos, não há como decidir qual método deve ser escolhido para determinar preços. E, para incomodar mais os não iniciados, alguns métodos recomendados para a alocação dos custos de produção aos produtos conjuntos baseiam-se no conhecimento prévio dos preços de venda dos produtos que deveriam se basear nos seus custos de produção, que são desconhecidos.

Enfim, estudar conceitos e técnicas de contabilidade para análise e tratamento contábil dos custos de produtos conjuntos e de subprodutos é importante porque eles são aplicados em várias empresas industriais e porque eles evidenciam alguns dos limites da contabilidade, que deveriam ser devidamente compreendidos por todos que preparam ou utilizam as demonstrações financeiras.

\subsubsection{Tratamento Contábil dos Custos dos Produtos Conjuntos e dos Subprodutos}

Nesta seção, são apresentados sumariamente os principais conceitos e técnicas para o tratamento contábil dos custos dos produtos conjuntos e dos subprodutos. Não serão feitas aqui, nem nas próximas seções as usuais referências aos autores das obras consultadas, mas é imprescindível esclarecer que o texto que se segue fundamenta-se livremente nas obras escritas pelos professores nomeados na seção anterior. 
Operações de decomposição ou análise são operações em que um ou mais materiais são processados para, a partir de um ponto denominado Ponto de Separação, dar origem a vários produtos. Esses produtos têm uma relação física que impede que um seja obtido independente dos demais. O refino do petróleo é um caso emblemático de operação de decomposição.

O processo que origina os vários produtos é chamado de Processo Conjunto, e os produtos que dele resultam são chamados genericamente de Produtos Conjuntos. Os custos incorridos nos processos conjuntos são conhecidos como Custos Conjuntos. Eles são incorridos para a fabricação de todos os produtos conjuntos e têm uma natureza distinta dos custos incorridos nos processos que dão origem a um único produto. Esses custos são denominados de Custos Separáveis ou Específicos.

Como as relações entre materiais, processos e produtos conjuntos são complexas e não observáveis, não há como determinar a contribuição dos diferentes fatores de produção utilizados nos processos para a produção de cada um dos produtos conjuntos. Logo, também não há como se apurar racionalmente os custos incorridos na fabricação de cada um dos produtos conjuntos.

Para preparar o balanço patrimonial e a demonstração do resultado de uma empresa, contadores precisam dividir os custos de produção entre as unidades de produtos que estão nos estoques e as unidades que foram vendidas. A impossibilidade de medir os custos dos fatores de produção empregados na fabricação de cada um dos produtos conjuntos obriga os contadores a recorrerem a métodos arbitrários para alocar os custos conjuntos aos produtos conjuntos. A única restrição é que, por força das normas de contabilidade, entre elas o regime de competência de exercícios, o método escolhido distribua todos os custos de produção a todos os produtos, seja usado de forma consistente ao longo do tempo, e seja devidamente explicitado nas notas explicativas que acompanham as demonstrações financeiras.

A escolha dos procedimentos usados na preparação das demonstrações financeiras é influenciada pela materialidade das transações que serão reportadas. No caso da opção por um método para alocação dos custos conjuntos aos produtos conjuntos, a materialidade leva os contadores a separarem os produtos conjuntos em duas categorias. Na primeira, estão os produtos principais, que são os mais importantes e cujos custos impactam mais no valor dos estoques e na formação dos resultados das empresas; e, na segunda, estão os subprodutos que são menos relevantes e cujos custos impactam menos no valor dos estoques e na formação dos resultados das empresas. A importância relativa dos produtos é medida usualmente pela parcela que suas vendas representam nas vendas totais das empresas. Os procedimentos propostos para a alocação dos custos de produção aos produtos principais são mais elaborados que os procedimentos propostos para os subprodutos.

Em geral, há três métodos distintos, mas igualmente válidos, para tratar contabilmente os subprodutos. O primeiro é não atribuir a eles nenhum valor. Nesse caso todos os custos conjuntos deverão ser divididos entre os produtos principais. A existência de estoques de subprodutos deverá ser reportada nas notas explicativas e, quando esses produtos forem vendidos, os valores auferidos deverão ser reportados como outras receitas operacionais.

O segundo método que pode ser usado para tratar os subprodutos é atribuir a eles o valor realizável líquido, que corresponde à diferença entre o preço estimado de venda menos os custos incorridos para acabá-los e vendê-los. Esse valor deverá ser deduzido dos custos conjuntos que serão alocados aos produtos principais. Vale registrar que esse método é referendado pelo CPC 16 (R1).

O terceiro método que pode ser usado para tratar os subprodutos é atribuir a eles o valor realizável líquido menos um valor de lucro considerado normal. Esse valor deverá ser deduzido dos custos conjuntos que serão alocados aos produtos principais.

Quanto aos métodos para alocação dos custos conjuntos aos produtos principais, há duas grandes categorias. Na primeira estão os métodos que alocam os custos com base nas quantidades de produtos fabricados. Entre eles está o método das unidades físicas, usado no caso da Refinaria Fluminense S.A. Esse método faz com que todos os produtos recebam o mesmo custo médio ponderado. Como o método das unidades físicas não leva em conta que diferentes produtos são comercializados a preços distintos, ele pode fazer com que alguns produtos pareçam indevidamente deficitários. 
Na segunda categoria de métodos para a alocação dos custos conjuntos aos produtos principais, estão os métodos baseados nos preços de venda dos produtos. Entre eles, está o método do valor realizável líquido. Esse método apropria os custos conjuntos aos produtos conjuntos principais na proporção da soma do valor final de venda da produção de cada produto menos seus custos específicos ou separáveis ${ }^{1}$. Ele deve ser usado nos casos em que ao menos um dos produtos principais não possa ser vendido no estado em que se encontra no ponto de separação, isto é, não haja preço de venda no ponto de separação para, ao menos, um dos produtos principais. Esse é o segundo método usado com alguns ajustes no caso da Refinaria Fluminense S.A.

É importante ressaltar que o referido método garante que todos os produtos sejam individualmente rentáveis, se o conjunto de produtos conjuntos for rentável. No entanto, como os custos específicos de cada produto podem variar, ele faz com que as margens percentuais de lucro dos produtos conjuntos principais sejam diferentes, após o cômputo dos custos específicos.

A Estrutura Conceitual para Elaboração e Divulgação de Relatório Contábil-Financeiro - CPC 00 (R1) afirma que, para serem úteis, as informações financeiras precisam ser relevantes e representar com fidedignidade o que se propõem a representar. Segundo a norma, as informações serão relevantes se a sua divulgação tiver o potencial de alterar as decisões que estão sendo analisadas pelos seus usuários.

Tomando-se como referência o critério para julgar a utilidade das informações financeiras expresso neste CPC, pode-se argumentar que os custos dos produtos conjuntos não são informações financeiras úteis porque são obtidos por meio de distribuições proporcionais que não refletem, necessariamente, a contribuição dos fatores de produção para a produção de cada produto conjunto e, como será comentado adiante, não devem ser usados para a análise de decisões. Ainda assim, por falta de opção, esses são os custos reportados nas demonstrações financeiras das empresas que realizam operações de decomposição.

\subsubsection{O Método do Valor Realizável Líquido em Ambientes com Múltiplos Pontos de Separação}

Lowenthal (1986) discutiu a questão da utilização do método do valor realizável líquido em ambientes com múltiplos pontos de separação como um problema prático que é comum de se encontrar em operações complexas e considerou duas soluções possíveis. A primeira se aplica quando os produtos intermediários possuem uma medida física comum. Nesse caso, ele propõe que o valor realizável líquido conjunto seja distribuído aos produtos intermediários na proporção da quantidade produzida de cada produto. No entanto, se os produtos intermediários não possuírem uma medida física comum, ele aventa a possibilidade de, simplesmente, distribuir o valor realizável líquido de forma arbitrária.

É imprescindível reconhecer que estas considerações são realmente muito pouco esclarecedoras. Sendo assim, pede-se que os leitores aguardem a apresentação da resposta oferecida para a questão 4 para verem objetivamente o problema e a solução proposta por Lowenthal (1986). A solução que se decidiu usar na resposta à questão 4 fundamenta-se no fato de que os produtos intermediários que compartilharão os valores realizáveis líquidos possuem medidas físicas comuns

1 É imprescindível destacar que esta apresentação do método do valor realizável líquido está em consonância com o que geralmente consta nos livros de contabilidade (ver, por exemplo, Horngren, Datar \& Rajan, 2012 e 2015, e Baker \& Jacobsen, 1974), mas não se aplica à situação encontrada na Refinaria Fluminense S.A. Os autores dos livros de contabilidade assumem que um ou mais produtos intermediários são obtidos de um processo conjunto, e alguns deles (ou todos) não são comercializáveis no estado em que se encontram. Por isso, são submetidos a processos separados para dar origem a produtos finais comercializáveis, quando esclarecem como se usa o método do valor realizável líquido. No entanto, na Refinaria Fluminense S.A. há produtos intermediários que resultam de processos conjuntos, e, por não serem comercializáveis, são submetidos a processos conjuntos que dão origem a dois ou mais derivados que têm preços de mercado. Ou seja, ela ilustra uma situação onde alguns produtos finais resultam de sequências de processos conjuntos. Portanto, pode-se argumentar que os ensinamentos dos livros subestimam a complexidade dos processos encontrados nas empresas, e, nesses casos, pouco ajudam os profissionais que os consultam. 


\subsubsection{Conceitos e Técnicas de Custos para Análise de Decisões}

Os capítulos dos livros que tratam dos custos dos produtos conjuntos e de subprodutos fazem menção a dois tipos de decisão. No primeiro, estão as decisões relativas ao grupo de produtos conjuntos e de subprodutos. E no segundo, estão as decisões referentes ao processamento adicional de cada um dos produtos conjuntos e dos subprodutos para agregar valor a eles.

$\mathrm{Na}$ análise das decisões relativas aos produtos conjuntos e subprodutos considerados como um grupo é irrelevante conhecer os custos de cada produto individual. A natureza das operações de decomposição obriga as empresas a fabricarem todos os produtos, ou não fabricar nenhum deles. Logo, o que se deve considerar é se a receita total da venda de todos os produtos é superior aos custos necessários para produzi-los e comercializá-los.

$\mathrm{Na}$ análise da decisão de processar um produto após o ponto de separação, os custos conjuntos são custos irrelevantes (sunk costs), dado que o produto já foi obtido. O processamento adicional deverá ser realizado sempre que a receita total incremental (receita na venda do produto após o processamento específico menos receita na venda do produto, tal como se encontra no ponto de separação) exceder o custo total incremental (o custo do processamento específico que será realizado).

\subsection{Sugestões para um Plano de Ensino}

O caso da Refinaria Fluminense S.A. foi concebido para ser examinado em uma sessão de cento e vinte minutos para discutir conceitos e técnicas de custos para a análise e o tratamento contábil dos custos dos produtos conjuntos e dos subprodutos. A sessão deve ser realizada, preferencialmente, com uma turma já familiarizada com tópicos básicos de custos, uma vez que a discussão exige que os participantes estejam familiarizados com os conceitos e classificações de custos, com os sistemas de acumulação de custos e com o modelo de análise incremental.

Como a análise do caso requer o conhecimento prévio das opções de tratamento contábil dos produtos conjuntos e dos subprodutos e dos modelos de análise de custos aplicáveis no contexto das operações de decomposição (ou análise), recomenda-se que os professores que planejam utilizar este caso insistam que os alunos leiam previamente os capítulos de um ou mais livros que tratem deste assunto com algum nível de detalhe. A bibliografia que integra este artigo, embora não seja exaustiva, enumera alguns livros que podem ser usados com proveito pelos alunos. Mas, certamente, há outros livros iguais ou melhores que os referenciados.

Caso pressintam que os alunos não terão condições de ler previamente os capítulos dos livros recomendados, os professores devem pensar seriamente em usar uma aula de cento e vinte minutos para apresentar formalmente o conteúdo que os alunos precisarão dominar para responder as questões e discutir o caso.

Considerando que os alunos terão que preparar um fluxograma e diversos quadros com cálculos para responder às questões, e que isso não poderá ser feito durante a aula em que o caso for discutido, sugere-se que os professores peçam para os alunos responderem às questões previamente. Dessa forma, o tempo da aula poderá ser dedicado à comparação dos encaminhamentos dados por diferentes grupos ou alunos e ao esclarecimento das dúvidas que porventura tenham surgido na elaboração das respostas.

É sempre interessante que os professores reservem algum tempo para que os alunos possam relatar as experiências que tiveram ou estão tendo com operações de decomposição. Se ninguém tiver tido esse tipo de vivência, é recomendável que os professores tomem a iniciativa de fornecer exemplos e contar casos de empresas que produzem e vendem produtos conjuntos e subprodutos. 
Destaca-se, por oportuno, que não é comum que os livros tragam exemplos de operações de decomposição realizados fora do ambiente industrial. Isso, porém, não significa que esses exemplos não existam ou não sejam relevantes. Um caso que pode ser mencionado, pela proeminência que tem, encontra-se no setor de entretenimento. Empresas como a Walt Disney Company e a Dreamworks, que produzem animações, realizam operações de decomposição na medida em que, além de venderem os direitos de exibição das animações, vendem os direitos de utilização dos personagens especialmente criados e de reprodução das trilhas sonoras dos filmes, entre as várias fontes de receita que resultam das animações que produziram.

\section{Referências}

Backer, M. \& Jacobsen, L.E. (1974). Contabilidade de custos: um enfoque para Administração de Empresas. São Paulo: McGraw-Hill do Brasil.

Cashin, J. A. \& Polimeni, R. S. (1981). Cost accounting. New York: McGraw-Hill.

Comitê de Pronunciamentos Contábeis (2011). Pronunciamento Conceitual Básico (R1): Estrutura Conceitual para Elaboração e Divulgação de Relatório Contábil - Financeiro Brasília.

(2013). Pronunciamento Técnico CPC 16 (R1) - Estoques - Brasília.

Hansen, D. R. \& Mowen, M. M. (2001). Gestão de custos. São Paulo: Pioneira Thompson Learning.

Horngren, C. T. (1972). Cost accounting: a managerial emphasis. (3rd. Ed.). Englewood Cliffs: Prentice Hall.

Horngren, C. T. \& Foster, G. (1987). Cost accounting: a managerial emphasis. (6th. Ed.). Englewood Cliffs: Prentice Hall.

Horngren, C. T.; Foster, G. \& Datar, S. M. (2000). Cost accounting: a managerial emphasis. (10th. Ed.). Englewood Cliffs: Prentice Hall.

Horngren, C. T.; Datar, S. M. \& Rajan, M. V. (2012). Cost accounting: a managerial emphasis. (14th. Ed.). Englewood Cliffs: Pearson Prentice Hall.

Horngren, C. T.; Datar, S. M. \& Rajan, M. V. (2015). Cost accounting: a managerial emphasis. (15th. Ed.). Englewood Cliffs: Pearson Prentice Hall.

Jiambalvo, J. (2009). Managerial accounting. (4th. ed.). Jonh Wiley \& Sons.

Kaplan, R. S. (2007) Sippican corporation (A) and (B) - teaching note. Harvard Business School, 5-107$085,14 \mathrm{p}$.

Lazzarini, W. (2005). Relatório de Impacto sobre o Meio Ambiente - Rima para modernização da Replan - Refinaria de Paulínia, Paulínia (SP) - Elaborado por Walter Lazzarini Consultoria Ambiental. São Paulo, SP, Brasil. Recuperado em 6 de julho, 2015, de http://www.comitepcj.sp.gov.br/download/ Replan-RIMA_Fase_II.pdf.

Lowenthal, F. (1986). Multiple Splitoff Points. Issues in Accounting Education. Fall 86(1) Issue 2, pp. 302 a 7.

Maher, M. (2001). Contabilidade de Custos: criando valor para a administração. (5a ed.). São Paulo: Atlas.

Martins, E. (2003). Contabilidade de custos. (9a ed.) São Paulo: Atlas.

Shillinglaw, G. (1982). Managerial cost accounting. (5th ed.). Homewood: Irwin. 


\section{Apêndice: Respostas Das Questões}

\section{Questão 1}

A Figura 1 apresenta o fluxograma do processo de produção da Refinaria Fluminense S.A.e as quantidades de produtos intermediários e finais obtidos do processamento de 12.500 .000 barris de petróleo, em dezembro de 2016.

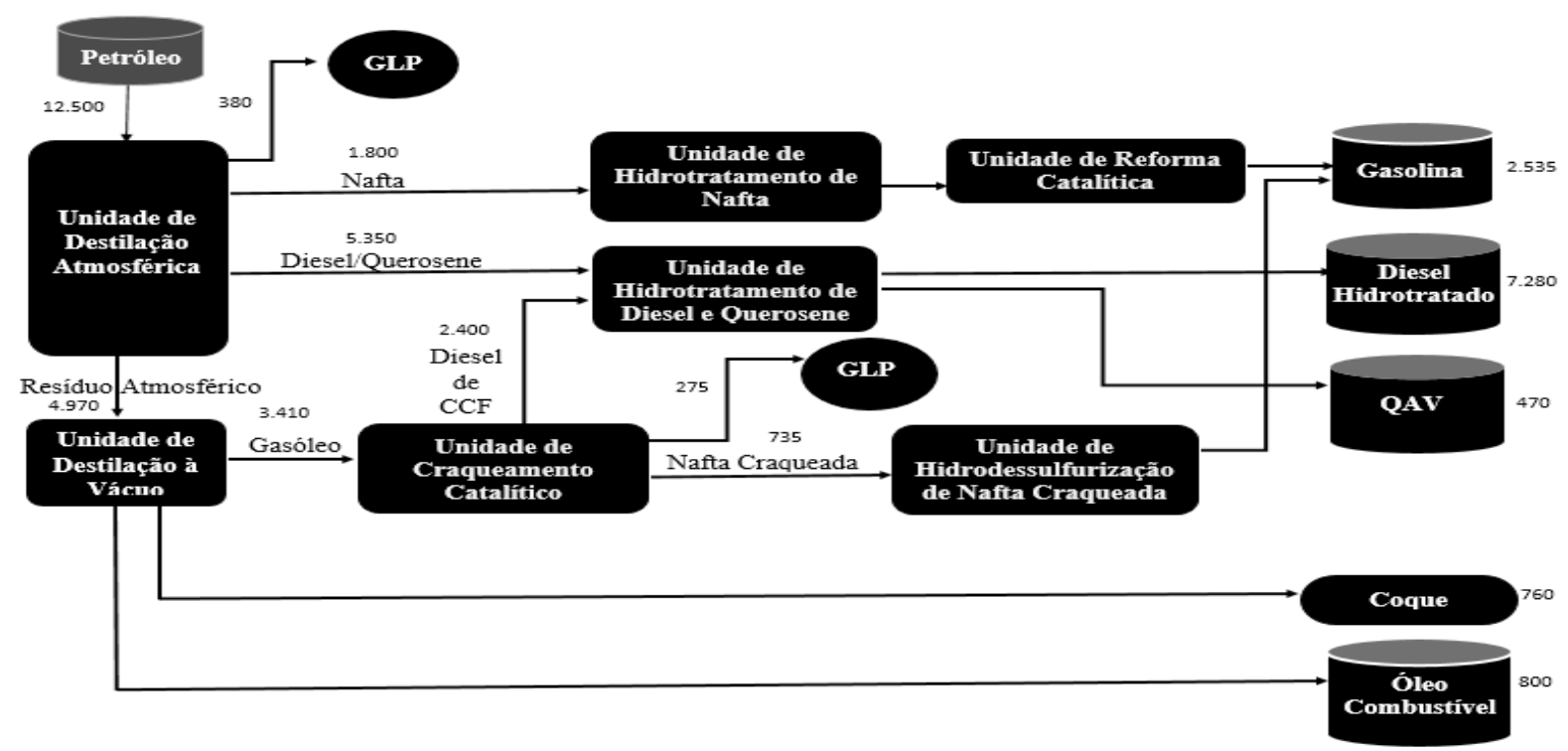

Figura 1. Fluxograma do processo de produção (em milhares de barris)

Fonte: Adaptado do Relatório de Impacto sobre o Meio Ambiente - RIMA para modernização da REPLAN - Refinaria de Paulínia, Paulínia (SP) - Lazzarini (2005).

Eventualmente, o professor que estiver planejando usar o caso pode considerar a possibilidade de anexar o fluxograma do processo de produção ao caso, se perceber que sua elaboração excederá as habilidades dos alunos.

\section{Questão 2}

Como todos os produtos fabricados em dezembro de 2016 foram vendidos, a receita total da Refinaria Fluminense S. A. foi de R $\$ 2.682 .828$ mil e a participação das vendas de cada produto nas vendas totais foi a seguinte: GLP - 1,416\%; Gasolina - 25,512\%; Diesel - 64,23\%; QAV - 3,994\%; Óleo Combustível - 4,771\%; Coque - 0,076\%.

Para separar os subprodutos dos produtos principais, com base no valor relativo de vendas, é necessário julgar a partir de que percentual um produto deve ser considerado relevante e, portanto, principal. Nesta análise, a escolha dos autores foi considerar somente o Coque como subproduto. Todos os demais produtos foram considerados principais porque suas vendas foram maiores que $1 \%$ das vendas totais. Mas deve-se mostrar aos alunos que essa é uma decisão arbitrária que afetará os procedimentos de apuração de custos, os valores dos estoques apresentados no balanço e o custo das mercadorias vendidas, que será comparado com a receita na demonstração do resultado.

Nesta análise, os autores optaram por não atribuir qualquer valor ao Coque, tendo em vista que esta é uma das três opções possíveis para o tratamento contábil dos subprodutos. Neste aspecto, a escolha e defesa do método de tratamento dos subprodutos por parte dos alunos é livre, não havendo resposta correta ou incorreta. 


\section{Questão 3}

Os Quadros de 4 a 8 apresentam os cálculos referentes à apuração de custos, dos resultados por produtos e do resultado da refinaria para o mês de dezembro de 2016, no pressuposto de que os custos conjuntos foram alocados aos produtos principais com base no método das unidades físicas.

Recomenda-se aos leitores que confrontem os quadros com o diagrama de fluxo apresentado na resposta à questão 1 .

Quadro 4

Unidade de Destilação Atmosférica

\begin{tabular}{lcccc}
\hline Produto & Quantidade (barris) & $\%$ & Custo Conjunto (R\$) & $\begin{array}{c}\text { Custo Unitário } \\
\text { (R\$/barril) }\end{array}$ \\
\hline GLP & 380.000 & 3,04 & $72.504 .000,00$ & 190,80 \\
\hline Nafta & 1.800 .000 & 14,40 & $343.440 .000,00$ & 190,80 \\
\hline Diesel/Querosene & 5.350 .000 & 42,80 & $1.020 .780 .000,00$ & 190,80 \\
\hline Resíduo Atmosférico & 4.970 .000 & 39,76 & $948.276 .000,00$ & 190,80 \\
\hline Total & 12.500 .000 & 100,00 & $2.385 .000 .000,00$ & \\
\hline
\end{tabular}

Fonte: os autores, 2016

Quadro 5

Unidade de Destilação à Vácuo

\begin{tabular}{lcccc}
\hline \multicolumn{1}{c}{ Produto } & Quantidade (barris) & \% & Custo Conjunto (R\$) & $\begin{array}{c}\text { Custo Unitário } \\
\text { (R\$/barril) }\end{array}$ \\
\hline Gasóleo & 3.410 .000 & 81,00 & $779.420 .703,09$ & 228,57 \\
\hline Óleo Combustível & 800.000 & 19,00 & $182.855 .296,91$ & 228,57 \\
\hline Total & 4.210 .000 & 100,00 & $962.276 .000,00$ & \\
\hline
\end{tabular}

Fonte: os autores, 2016.

Quadro 6

Unidade de Craqueamento Catalítico

\begin{tabular}{lcccc}
\hline Produto & Quantidade (barris) & $\%$ & Custo Conjunto (R\$) & $\begin{array}{c}\text { Custo Unitário } \\
\text { (R\$/barril) }\end{array}$ \\
\hline Diesel de CCF & 2.400 .000 & 70,38 & $563.345 .949,39$ & 234,73 \\
\hline GLP & 275.000 & 8,06 & $64.550 .056,70$ & 234,73 \\
\hline Nafta Craqueada & 735.000 & 21,55 & $172.524 .697,00$ & 234,73 \\
\hline Total & 3.410 .000 & 100,00 & $800.420 .703,09$ & \\
\hline
\end{tabular}

Fonte: os autores, 2016. 
Quadro 7

Unidade de Hidrotratamento de Diesel e Querosene

\begin{tabular}{lcccc}
\hline Produto & Quantidade (barris) & \% & Custo Conjunto (R\$) & $\begin{array}{c}\text { Custo Unitário } \\
\text { (R\$/barril) }\end{array}$ \\
\hline Diesel Hidrotratado & 7.280 .000 & 93,94 & $1.506 .655 .601,49$ & 206,96 \\
\hline QAV & 470.000 & 6,06 & $97.270 .347,90$ & 206,96 \\
\hline Total & 7.750 .000 & 100,00 & $1.603 .925 .949,39$ & \\
\hline
\end{tabular}

Fonte: os autores, 2016

Quadro 8

Demonstração de Resultado dezembro de 2016 pelo método das unidades físicas

\begin{tabular}{|c|c|c|c|c|c|c|c|}
\hline & Gasolina & $\begin{array}{c}\text { Diesel } \\
\text { Hidrotratado }\end{array}$ & $\begin{array}{l}\text { Querosene } \\
\text { de Aviação }\end{array}$ & $\begin{array}{c}\text { Óleo } \\
\text { Combustível }\end{array}$ & $\begin{array}{l}\text { Gas } \\
\text { Liquefeito de } \\
\text { Petróleo }\end{array}$ & Coque & $\begin{array}{c}\text { Refinaria } \\
\text { Fluminense }\end{array}$ \\
\hline Quantidade (barris) & 2.535 .000 & 7.280 .000 & 470.000 & 800.000 & 655.000 & 760.000 & \\
\hline Preço/bbl & 270,00 & 236,70 & 228,00 & 160,00 & 58,00 & 2,70 & \\
\hline Receita Total (R\$) & $684.450 .000,00$ & $1.723 .176 .000,00$ & $107.160 .000,00$ & $128.000 .000,00$ & $37.990 .000,00$ & $2.052 .000,00$ & $2.682 .828 .000,00$ \\
\hline \multicolumn{8}{|l|}{ Custos (R\$) } \\
\hline Diesel & & $1.506 .655 .601,49$ & & & & & \\
\hline $\begin{array}{l}\text { Querosene de } \\
\text { Aviação }\end{array}$ & & & $97.270 .347,90$ & & & & \\
\hline Óleo Combustível & & & & $182.855 .296,91$ & & & \\
\hline $\begin{array}{l}\text { Gás Liquefeito de } \\
\text { Petróleo }\end{array}$ & & & & & $137.054 .056,70$ & & \\
\hline Nafta & $343.440 .000,00$ & & & & & & \\
\hline Nafta Craqueada & $172.524 .697,00$ & & & & & & \\
\hline $\begin{array}{l}\text { Hidrotratamento de } \\
\text { Nafta }\end{array}$ & $7.000 .000,00$ & & & & & & \\
\hline Reforma Catalítica & $10.000 .000,00$ & & & & & & \\
\hline $\begin{array}{l}\text { Hidrodessulfurização } \\
\text { de Nafta Craqueada }\end{array}$ & $5.000 .000,00$ & & & & & & \\
\hline Custo Total & $537.964 .697,00$ & $1.506 .655 .601,49$ & $97.270 .347,90$ & $182.855 .296,91$ & $137.054 .056,70$ & & $2.461 .800 .000,00$ \\
\hline Lucro Bruto (R\$) & $146.485 .303,00$ & $216.520 .398,51$ & $9.889 .652,10$ & $-54.855 .296,91$ & $-99.064 .056,70$ & & $221.028 .000,00$ \\
\hline LB (R\$/barril) & 57,79 & 29,74 & 21,04 & $-68,57$ & $-151,24$ & & \\
\hline $\begin{array}{l}\text { Despesa de venda } \\
(\mathrm{R} \$)\end{array}$ & & & & & & $52.000,00$ & $52.000,00$ \\
\hline Lucro $(R \$)$ & & & & & & $2.000 .000,00$ & $220.976 .000,00$ \\
\hline
\end{tabular}

Fonte: os autores, 2016

Conforme se pode observar nos Quadros 4 a 7, todas as alocações de custos fizeram com que os custos unitários dos produtos fossem iguais, como era esperado. Ademais, como a alocação dos custos conjuntos não levou em conta os preços de venda dos produtos, dois produtos acabaram parecendo indevidamente deficitários, conforme evidenciado em negrito no Quadro 8. 


\section{Questão 4}

Os Quadros de 9 a 19 apresentam os cálculos referentes à apuração de custos, dos resultados por produtos e do resultado da refinaria para o mês de dezembro de 2016, no pressuposto de que os custos conjuntos foram alocados aos produtos principais com base no método do valor realizável líquido.

Recomenda-se mais uma vez que os leitores confrontem os quadros com o diagrama de fluxo apresentado na resposta à questão 1 .

A apresentação padrão do método do valor realizável líquido nos textos didáticos assume que um processo conjunto origina dois produtos conjuntos intermediários que são processados separadamente para se converterem em dois produtos principais que são comercializados regularmente; e que os produtos conjuntos intermediários não têm preços de mercado conhecidos porque não são comercializados no estado em que se encontram no ponto de separação. Nesse caso, a determinação dos valores realizáveis líquidos dos produtos intermediários é feita pela dedução dos custos dos processos separados dos valores de venda dos produtos principais produzidos.

Diferentemente, na Refinaria Fluminense S.A. há sequências de pontos de separação. Por exemplo, a Unidade de Destilação Atmosférica produz quatro produtos conjuntos, entre eles a mistura Diesel/Querosene; e a Unidade de Craqueamento Catalítico produz três produtos, entre eles o Diesel de CCF. Nenhum desses produtos é comercializado regularmente e, logo, não têm preços de mercado.

A mistura Diesel/Querosene e o Diesel de CCF são processados na Unidade de Hidrotratamento de Diesel/Querosene para originar o Diesel Hidrotratado e o Querosene de Aviação. Comparando-se esta situação com a apresentação padrão dos textos didáticos, fica evidente que os ensinamentos usuais são insuficientes para distribuir os custos da Unidade de Destilação Atmosférica e da Unidade de Craqueamento Catalítico com base no método do valor realizável líquido.

Uma possível solução para este problema é oferecida por Lowenthal (1986). Ela consiste em dividir o valor obtido pela dedução do custo da Unidade de Hidrotratamento de Diesel/Querosene da soma dos valores de venda da produção de Diesel Hidrotratado e de Querosene de Aviação na proporção das quantidades produzidas da mistura Diesel/Querosene e de Diesel de CCF, dado que esses dois produtos possuem a mesma unidade física de medida. Certamente, esta não é a única situação na Refinaria Fluminense S.A. em que os ensinamentos convencionais são insuficientes e que demanda a aplicação da solução proposta por Lowenthal (1986). Assim sendo, a solução adotada para a determinação dos valores realizáveis líquidos da mistura Diesel/Querosene e do Diesel de CCF também foi usada nos demais casos onde problemas similares ocorreram, como se poderá observar nos Quadros de 9 a 19.

Quadro 9

Valor Realizável Líquido da Nafta e da Nafta Craqueada

\begin{tabular}{lccccccc}
\hline Produto & $\begin{array}{c}\text { Quantidade } \\
\text { (barris) }\end{array}$ & $\begin{array}{c}\text { Preço } \\
\text { (R\$) }\end{array}$ & $\begin{array}{c}\text { Valor de } \\
\text { Venda (R\$) }\end{array}$ & $\begin{array}{c}\text { Hidrotratamento } \\
\text { de Nafta (R\$) }\end{array}$ & $\begin{array}{c}\text { Reforma } \\
\text { Catalítica } \\
\text { (R\$) }\end{array}$ & $\begin{array}{c}\text { Hidrodessulfurização } \\
\text { de Nafta Craqueada } \\
\text { (R\$) }\end{array}$ & $\begin{array}{c}\text { Valor } \\
\text { Realizável } \\
\text { Líquido } \\
\text { (R\$) }\end{array}$ \\
\hline Nafta & 1.800 .000 & 270 & 486.000 .000 & 7.000 .000 & 10.000 .000 & & 469.000 .000 \\
\hline $\begin{array}{l}\text { Nafta } \\
\text { Craqueada }\end{array}$ & 735.000 & 270 & 198.450 .000 & & & 5.000 .000 & 193.450 .000 \\
\hline Total & 2.535 .000 & & & & & & \\
\hline
\end{tabular}

Fonte: os autores, 2016. 
Quadro 10

Valor Realizável Líquido do Diesel CCF e do Diesel /Querosene

\begin{tabular}{lcccccc}
\hline Produto & $\begin{array}{c}\text { Quantidade } \\
\text { (barris) }\end{array}$ & $\begin{array}{c}\text { Preço } \\
(\mathbf{R} \$)\end{array}$ & $\begin{array}{c}\text { Valor de Venda } \\
\mathbf{( R \$ )}\end{array}$ & $\begin{array}{c}\text { Hidrotratamento } \\
\text { de Diesel } \\
\text { Querosene (R\$) }\end{array}$ & $\begin{array}{c}\text { Valor Realizável } \\
\text { Líquido (R\$) }\end{array}$ & VRL (R\$/barril) \\
\hline $\begin{array}{l}\text { Diesel } \\
\text { Hidrotratado }\end{array}$ & 7.280 .000 & 236,70 & $1.723 .176 .000,00$ & & & \\
\hline $\begin{array}{l}\text { Querosene } \\
\text { de Aviação }\end{array}$ & 470.000 & 228,00 & $107.160 .000,00$ & & & \\
\hline Total & 7.750 .000 & & $1.830 .336 .000,00$ & $19.800 .000,00$ & $1.810 .536 .000,00$ & 233,62 \\
\hline
\end{tabular}

Fonte: os autores, 2016.

Quadro 11

Valor Realizável Líquido do Gasóleo

\begin{tabular}{lcccc}
\multicolumn{1}{c}{ Produto } & $\begin{array}{c}\text { Valor Estimado } \\
\text { de Venda (R\$) }\end{array}$ & $\begin{array}{c}\text { Craqueamento } \\
\text { Catalítico (R\$) }\end{array}$ & $\begin{array}{c}\text { Valor Realizável } \\
\text { Líquido do } \\
\text { Gasóleo (R\$) }\end{array}$ & $\begin{array}{c}\text { Quantidade } \\
\text { (barris) }\end{array}$ \\
\hline Diesel CCF & $560.682 .116,13$ & & & VRL (R\$/barril) \\
\hline GLP & $15.950 .000,00$ & & & \\
\hline Nafta Craqueada & $193.450 .000,00$ & & $749.082 .116,13$ & $3.410 .000,00$ \\
\hline Total & $770.082 .116,13$ & $21.000 .000,00$ & & 219,67 \\
\hline
\end{tabular}

Fonte: os autores, 2016.

Quadro 12

Valor Realizável Líquido do Resíduo Atmosférico

\begin{tabular}{lccc}
\hline Produto & $\begin{array}{c}\text { Valor Estimado de Venda } \\
(\mathbf{R} \$)\end{array}$ & Destilação à Vácuo (R\$) & $\begin{array}{c}\text { Valor Realizável Líquido } \\
\text { do Resíduo Atmosférico } \\
\text { (R\$) }\end{array}$ \\
\hline Gasóleo & $749.082 .116,13$ & \\
\hline Óleo Combustível & $128.000 .000,00$ & & \\
\hline Total & $877.082 .116,13$ & $14.000 .000,00$ & $863.082 .116,13$ \\
\hline
\end{tabular}

Fonte: os autores, 2016.

Quadro 13

Distribuição dos Custos da Unidade de Destilação Atmosférica

\begin{tabular}{lccccc}
\hline \multicolumn{1}{c}{ Produto } & $\begin{array}{c}\text { Quantidade } \\
\text { (barris) }\end{array}$ & $\begin{array}{c}\text { Valor Realizável } \\
\text { Líquido (R\$) }\end{array}$ & $\mathbf{\%}$ & $\begin{array}{c}\text { Custo Conjunto } \\
\text { (R\$) }\end{array}$ & Custo (R\$/barril) \\
\hline GLP & 380.000 & $22.040 .000,00$ & 0,85 & $20.186 .591,58$ & 53,12 \\
\hline Nafta & 1.800 .000 & $469.000 .000,00$ & 18,01 & $429.560 .410,70$ & 238,64 \\
\hline Diesel/Querosene & 5.350 .000 & $1.249 .853 .883,87$ & 48,00 & $1.144 .749 .995,02$ & 213,97 \\
\hline $\begin{array}{l}\text { Resíduo } \\
\text { Atmosférico }\end{array}$ & 4.970 .000 & $863.082 .116,13$ & 33,14 & $790.503 .002,70$ & 159,05 \\
\hline Total & 12.500 .000 & $2.603 .976 .000,00$ & 100,00 & $2.385 .000 .000,00$ & \\
\hline
\end{tabular}

Fonte: os autores, 2016. 
Quadro 14

Distribuição dos Custos da Unidade de Destilação à Vácuo

\begin{tabular}{lccccc}
\hline \multicolumn{1}{c}{ Produto } & $\begin{array}{c}\text { Quantidade } \\
\text { (barris) }\end{array}$ & $\begin{array}{c}\text { Valor Realizável } \\
\text { Líquido (R\$) }\end{array}$ & $\%$ & $\begin{array}{c}\text { Custo Conjunto } \\
\text { (R\$) }\end{array}$ & Custo (R\$/barril) \\
\hline Gasóleo & 3.410 .000 & $749.082 .116,13$ & 85,41 & $687.095 .085,64$ & 201,49 \\
\hline Óleo Combustível & 800.000 & $128.000 .000,00$ & 14,59 & $117.407 .917,06$ & 146,76 \\
\hline Total & 4.210 .000 & $877.082 .116,13$ & 100,00 & $804.503 .002,70$ & \\
\hline
\end{tabular}

Fonte: os autores, 2016.

Quadro 15

Distribuição dos Custos da Unidade de Craqueamento Catalítico

\begin{tabular}{lccccc}
\hline \multicolumn{1}{c}{ Produto } & $\begin{array}{c}\text { Quantidade } \\
\text { (barris) }\end{array}$ & $\begin{array}{c}\text { Valor Realizável } \\
\text { Líquido (R\$) }\end{array}$ & $\%$ & $\begin{array}{c}\text { Custo Conjunto } \\
\text { (R\$) }\end{array}$ & Custo (R\$/barril) \\
\hline Diesel CCF & 2.400 .000 & $560.682 .116,13$ & 72,81 & $515.550 .540,29$ & 214,81 \\
\hline GLP & 275.000 & $15.950 .000,00$ & 2,07 & $14.666 .119,86$ & 53,33 \\
\hline Nafta Craqueada & 735.000 & $193.450 .000,00$ & 25,12 & $177.878 .425,49$ & 242,01 \\
\hline Total & 3.410 .000 & $770.082 .116,13$ & 100,00 & $708.095 .085,64$ & \\
\hline
\end{tabular}

Fonte: os autores, 2016

Quadro 16

Custo Médio do Gás Liquefeito de Petróleo

\begin{tabular}{lccc}
\multicolumn{1}{c}{ Origem } & Custo de Produção (R\$) & Quantidade(barris) & Custo (R\$/barril) \\
\hline Destilação Atmosférica & $20.186 .591,58$ & 380.000 & 53,12 \\
\hline Craqueamento Catalítico & $14.666 .119,86$ & 275.000 & 53,33 \\
\hline Total & $34.852 .711,44$ & 655.000 & 53,21 \\
\hline
\end{tabular}

Fonte: os autores, 2016.

Quadro 17

Distribuição do Custo da Unidade de Hidrotratamento de Diesel/Querosene

\begin{tabular}{|c|c|c|c|c|c|c|}
\hline Produto & $\begin{array}{c}\text { Diesel / } \\
\text { Querosene (R\$) }\end{array}$ & $\begin{array}{c}\text { Diesel CCF } \\
\text { (R\$) }\end{array}$ & $\begin{array}{c}\text { Hidrotratamento } \\
\text { de Diesel e } \\
\text { Querosene (R\$) }\end{array}$ & Custo & $\begin{array}{c}\text { Diesel } \\
\text { Hidrotratado }\end{array}$ & $\begin{array}{c}\text { Querosene de } \\
\text { Aviação }\end{array}$ \\
\hline $\begin{array}{l}\text { Diesel/ } \\
\text { Querosene }\end{array}$ & $1.144 .749 .995,02$ & & & & & \\
\hline Diesel CCF & & $515.550 .540,29$ & & & & \\
\hline Total (R\$) & $1.144 .749 .995,02$ & $515.550 .540,29$ & $19.800 .000,00$ & 1.680.100.535,31 & & \\
\hline $\begin{array}{l}\text { Quantidade } \\
\text { Total } \\
\text { (barris) }\end{array}$ & & & & $7.750 .000,00$ & & \\
\hline $\begin{array}{l}\text { Custo }(\mathrm{R} \$ / \\
\text { barril) }\end{array}$ & & & & 216,79 & 216,79 & 216,79 \\
\hline $\begin{array}{l}\text { Quantidade } \\
\text { (barris) }\end{array}$ & & & & & 7.280 .000 & 470.000 \\
\hline $\begin{array}{l}\text { Custo Total } \\
\text { (R\$) }\end{array}$ & & & & & $1.578 .210 .567,36$ & $101.889 .967,95$ \\
\hline
\end{tabular}

Fonte: os autores, 2016. 
Quadro 18

Custo da Gasolina

\begin{tabular}{lccccc}
\hline \multicolumn{1}{c}{ Produto } & $\begin{array}{c}\text { Custo de } \\
\text { Produção (R\$) }\end{array}$ & $\begin{array}{c}\text { Reforma } \\
\text { Catalítica (R\$) }\end{array}$ & $\begin{array}{c}\text { Hidrotratamento } \\
\text { de Nafta (R\$) }\end{array}$ & $\begin{array}{c}\text { Hidrodessulfurização } \\
\text { de Nafta Craqueada } \\
\text { (R\$) }\end{array}$ & Total (R\$) \\
\hline Nafta & $429.560 .410,70$ & $10.000 .000,00$ & $7.000 .000,00$ & & $446.560 .410,70$ \\
\hline Nafta Craqueada & $177.878 .425,49$ & & & $5.000 .000,00$ & $182.878 .425,49$ \\
\hline Total & $607.438 .836,19$ & $10.000 .000,00$ & $7.000 .000,00$ & $5.000 .000,00$ & $629.438 .836,19$ \\
\hline Quantidade & & & & & 2.535 .000 \\
\hline $\begin{array}{l}\text { Custo Unitário } \\
\text { (R\$/barril) }\end{array}$ & & & & 248,30 \\
\hline
\end{tabular}

Fonte: os autores, 2016

Quadro 19

Demonstração de Resultado dezembro de 2016 pelo método do valor realizável líquido

\begin{tabular}{|c|c|c|c|c|c|c|c|}
\hline & Gasolina & $\begin{array}{c}\text { Diesel } \\
\text { Hidrotratado }\end{array}$ & $\begin{array}{l}\text { Querosene de } \\
\text { Aviação }\end{array}$ & $\begin{array}{c}\text { Óleo } \\
\text { Combustível }\end{array}$ & $\begin{array}{l}\text { Gás Liquefeito } \\
\text { de Petróleo }\end{array}$ & Coque & $\begin{array}{c}\text { Refinaria } \\
\text { Fluminense }\end{array}$ \\
\hline $\begin{array}{l}\text { Quantidade } \\
\text { (barris) }\end{array}$ & 2.535 .000 & 7.280 .000 & 470.000 & 800.000 & 655.000 & 760.000 & \\
\hline $\begin{array}{l}\text { Preço (R\$/ } \\
\text { barril) }\end{array}$ & 270,00 & 236,70 & 228,00 & 160,00 & 58,00 & 2,70 & \\
\hline $\begin{array}{l}\text { Receita Total } \\
(\mathrm{R} \$)\end{array}$ & $684.450 .000,00$ & $1.723 .176 .000,00$ & $107.160 .000,00$ & $128.000 .000,00$ & $37.990 .000,00$ & 2.052 .000 & 2.682 .828 .000 \\
\hline \multicolumn{8}{|l|}{ Custos (R\$) } \\
\hline Gasolina & $629.438 .836,19$ & & & & & & \\
\hline Diesel & & $1.578 .210 .567,36$ & & & & & \\
\hline $\begin{array}{l}\text { Querosene de } \\
\text { Aviação }\end{array}$ & & & $101.889 .967,95$ & & & & \\
\hline $\begin{array}{l}\text { Óleo } \\
\text { Combustível }\end{array}$ & & & & $117.407 .917,06$ & & & \\
\hline $\begin{array}{l}\text { Gás Liquefeito } \\
\text { de Petróleo }\end{array}$ & & & & & $34.852 .711,44$ & & \\
\hline Custo Total & $629.438 .836,19$ & $1.578 .210 .567,36$ & $101.889 .967,95$ & $117.407 .917,06$ & $34.852 .711,44$ & & 2.461 .800 .000 \\
\hline $\begin{array}{l}\text { Lucro Bruto } \\
(\mathrm{R} \$)\end{array}$ & $55.011 .163,81$ & $144.965 .432,64$ & $5.270 .032,05$ & $10.592 .082,94$ & $3.137 .288,56$ & & 221.028 .000 \\
\hline LB (R\$/barril) & 21,70 & 19,91 & 11,21 & 13,24 & 4,79 & & \\
\hline $\begin{array}{l}\text { Despesa de } \\
\text { venda }(R \$)\end{array}$ & & & & & & 52.000 & 52.000 \\
\hline Lucro (R\$) & & & & & & 2.000 .000 & 220.976 .000 \\
\hline
\end{tabular}

Fonte: os autores, 2016.

Conforme está evidente nos Quadros de 13 a 16, todas as alocações de custos fizeram com que os custos unitários dos produtos fossem diferentes, como era esperado. Ademais, como a alocação dos custos conjuntos levou em conta os preços de venda dos produtos, todos os produtos foram individualmente rentáveis, uma vez que, em conjunto, eles são rentáveis. A despeito disso, as margens de lucro dos diferentes produtos foram distintas, novamente conforme esperado. 


\section{Questão 5}

$\mathrm{Na}$ análise da decisão de processar um produto após o ponto de separação, os custos conjuntos são irrelevantes (sunk costs), dado que o produto já foi obtido. O processamento adicional deverá ser realizado sempre que a receita incremental exceder o custo incremental.

Considerando que o processamento adicional da gasolina comum para transformá-la em Gasolina Master gerará uma receita incremental de $\mathrm{R} \$ 30,00(\mathrm{R} \$ 300-\mathrm{R} \$ 270)$ por barril, e obrigará a refinaria a incorrer em um custo incremental de $\mathrm{R} \$ 10$ por barril; cada barril de Gasolina Master produzido e vendido aumentará o lucro da Refinaria Fluminense S.A. em R $\$ 20$. Assim, deve-se recomendar aos executivos a produção e venda da Gasolina Master.

Aplicando-se a mesma lógica no caso do Diesel Master, percebe-se que haverá uma receita incremental no valor de $\mathrm{R} \$ 13,30$ ( $\mathrm{R} \$ 250$ - $\mathrm{R} \$ 236,70$ ) e um custo incremental de $\mathrm{R} \$ 9,00$, fazendo com que cada litro de Diesel Master produzido e vendido aumente o lucro da refinaria em $\mathrm{R} \$ 4,70$. Portanto, deve-se recomendar que o Diesel Master também seja produzido e vendido.

\section{Questão 6}

A análise da decisão de não submeter um produto a um processo adicional deve seguir o mesmo modelo da análise da decisão de submeter um produto a um processo adicional. Nesse caso, o que se quer saber é se a economia com a não realização do processo adicional superará a redução da receita que haverá pela venda de um produto com menor valor agregado. Destaca-se que a composição dos custos que serão eliminados dependerá do tamanho e do horizonte de tempo da decisão. Nas decisões marginais, só serão eliminados os custos variáveis; e, nas decisões de longo prazo, serão eliminados alguns custos fixos, além dos custos variáveis.

É imprescindível esclarecer que, como as vendas cogitadas na questão serão eventuais, as economias nos custos das operações de Hidrotratamento da Nafta, de Reforma Catalítica, e de Hidrodessulfurização da Nafta Craqueada serão limitadas aos custos variáveis. No caso da Nafta, para cada barril vendido, a refinaria abrirá mão de $\mathrm{R} \$ 20$ (preço da gasolina menos o preço da nafta). Por outro lado, serão economizados R\$3/barril, referentes aos custos variáveis da Unidade de Hidrotratamento de Nafta, e R \$ 4/barril, referentes aos custos variáveis da Unidade de Reforma Catalítica. Dessa forma, a cada barril de nafta vendido, a refinaria deixará de ganhar $\mathrm{R} \$ 13,00$. Portanto, a proposta de venda de nafta não é vantajosa.

No caso da Nafta Craqueada, a refinaria abrirá mão dos mesmos R $\$ 20$ (preço da gasolina menos o preço da nafta). Por outro lado, serão economizados $\mathrm{R} \$ 5 /$ barril, referentes aos custos variáveis da Unidade de Hidrodessulfurização de Nafta Craqueada. Assim, a cada barril de nafta craqueada vendido, a refinaria deixará de ganhar $\mathrm{R} \$ 15,00$. Portanto, a proposta de venda de nafta craqueada também não é vantajosa.

\section{Questão 7}

Considerando que o custo adicional esperado por barril de diesel produzido será de $\mathrm{R} \$ 32$, no caso da exigência de reenquadramento da emissão de enxofre, para a produção atual de 7.280 mil barris de diesel por mês, haverá um custo adicional da ordem de $\mathrm{R} \$ 233$ milhões por mês, incompatível, portanto, com o resultado da refinaria da ordem de $\mathrm{R} \$ 221$ milhões por mês. A refinaria deve se posicionar no sentido de que esse tipo de exigência só será economicamente viável com o repasse do custo adicional no preço de venda do diesel. 


\section{Questão 8}

Os Quadros 20 e 21 apresentam os preços de venda, e os custos unitários apurados, respectivamente, segundo os métodos das unidades físicas e do valor realizável líquido, e os lucros unitários de cada derivado produzido na Refinaria Fluminense S.A.

Quadro 20

Resultado unitário por derivado apurado com base no método das unidades físicas

\begin{tabular}{lcccc}
\hline Produto & Volume (barris) & Preço (R\$/barril) & $\begin{array}{c}\text { Custo/Despesa } \\
\text { (R\$/barril) }\end{array}$ & $\begin{array}{c}\text { Resultado } \\
\text { (R\$/barril) }\end{array}$ \\
\hline $\mathrm{GLP}$ & 655.000 & $\mathrm{R} \$ 58,00$ & $\mathrm{R} \$ 209,24$ & $-\mathrm{R} \$ 151,24$ \\
\hline Gasolina & 2.535 .000 & $\mathrm{R} \$ 270,00$ & $\mathrm{R} \$ 212,21$ & $\mathrm{R} \$ 57,79$ \\
\hline Diesel & 7.280 .000 & $\mathrm{R} \$ 236,70$ & $\mathrm{R} \$ 206,96$ & $\mathrm{R} \$ 29,74$ \\
\hline $\mathrm{QAV}$ & 470.000 & $\mathrm{R} \$ 228,00$ & $\mathrm{R} \$ 206,96$ & $\mathrm{R} \$ 21,04$ \\
\hline O. Comb. & 800.000 & $\mathrm{R} \$ 160,00$ & $\mathrm{R} \$ 228,57$ & $-\mathrm{R} \$ 68,57$ \\
\hline Coque & 760.000 & $\mathrm{R} \$ 2,70$ & $\mathrm{R} \$ 0,07$ & $\mathrm{R} \$ 2,63$ \\
\hline Total Refinaria & 12.500 .000 & $\mathrm{R} \$ 214,63$ & $\mathrm{R} \$ 196,95$ & $\mathrm{R} \$ 17,68$ \\
\hline
\end{tabular}

Fonte: os autores, 2016.

Quadro 21

Resultado unitário por derivado apurado com base no método do valor realizável líquido

\begin{tabular}{lcccc} 
Produto & Volume (barris) & Preço (R\$/barril) & $\begin{array}{c}\text { Custo/Despesa } \\
\text { (R\$/barril) }\end{array}$ & $\begin{array}{c}\text { Resultado } \\
\text { (R\$/barril) }\end{array}$ \\
\hline $\mathrm{GLP}$ & 655.000 & $\mathrm{R} \$ 58,00$ & $\mathrm{R} \$ 53,21$ & $\mathrm{R} \$ 4,79$ \\
\hline Gasolina & 2.535 .000 & $\mathrm{R} \$ 270,00$ & $\mathrm{R} \$ 248,30$ & $\mathrm{R} \$ 21,70$ \\
\hline Diesel & 7.280 .000 & $\mathrm{R} \$ 236,70$ & $\mathrm{R} \$ 216,79$ & $\mathrm{R} \$ 19,91$ \\
\hline $\mathrm{QAV}$ & 470.000 & $\mathrm{R} \$ 228,00$ & $\mathrm{R} \$ 216,79$ & $\mathrm{R} \$ 11,21$ \\
\hline O. Comb. & 800.000 & $\mathrm{R} \$ 160,00$ & $\mathrm{R} \$ 146,76$ & $\mathrm{R} \$ 13,24$ \\
\hline Coque & 760.000 & $\mathrm{R} \$ 2,70$ & $\mathrm{R} \$ 0,07$ & $\mathrm{R} \$ 2,63$ \\
\hline Total Refinaria & 12.500 .000 & $\mathrm{R} \$ 214,63$ & $\mathrm{R} \$ 196,95$ & $\mathrm{R} \$ 17,68$ \\
\hline
\end{tabular}

Fonte: os autores, 2016.

Como todos os derivados produzidos em dezembro de 2016 foram vendidos, os dois métodos de distribuição de custos conjuntos levam ao mesmo resultado total para a refinaria (ver Quadros de 8 e 19). No entanto, os custos e os resultados unitários por derivado obtidos com os dois métodos são diferentes (ver as Quadros 20 e 21).

A principal vantagem do método das unidades físicas é que ele é fácil de compreender, de implantar e de usar. Porém, eventualmente, pode gerar informações distorcidas, como nos casos do GLP e do Óleo Combustível. É possível demonstrar que, se a refinaria deixar de produzir e vender esses produtos, sua receita total reduzirá mais que os custos que ela eliminará, reduzindo seu lucro, o que denota que ambos os produtos são rentáveis. Apesar disso, o método das unidades físicas imputa a esses produtos custos superiores às receitas que eles geram, sugerindo indevidamente que eles são deficitários (ver a Quadro 20).

A escolha, pelo aluno, de um dos métodos propostos nas questões 3 e 4 é livre, não havendo resposta correta ou mais apropriada, objetivando que, após a elaboração de todos os cálculos e análises, ele seja capaz de perceber, por experiência própria, ao desenvolver o caso, as vantagens e desvantagens dos métodos trabalhados e tenha condições de formar uma opinião a respeito e defender seu ponto de vista. 
A principal vantagem do método do valor realizável líquido é que ele leva em conta o preço de vendas dos produtos na distribuição dos custos conjuntos e, consequentemente, garante que, se em grupo todos os produtos são rentáveis, todos os produtos individualmente também o serão. Contudo, deve-se observar que, nesse caso, as margens de lucro dos diferentes produtos serão diferentes sempre que os custos dos processos específicos forem distintos. Comparado especialmente com o método das unidades físicas, o método do valor realizável líquido peca por ser mais complexo e trabalhoso. Isso fica evidente nos cálculos feitos para responder às questões 3 e 4 deste caso.

As informações obtidas por meio dos métodos das unidades físicas e do valor realizável líquido, por não refletirem as contribuições dos fatores de produção para a obtenção de cada um dos derivados, não representam fidedignamente os custos dos produtos e, portanto, não são informações financeiras úteis nos termos do CPC 00 (R1). Mas, por resultarem da alocação de todos os custos de produção a todos os produtos, essas informações atendem às normas de contabilidade e podem ser usadas na preparação das demonstrações financeiras. As únicas restrições são que, tendo escolhido um método, os contadores o utilizem de forma consistente e o declarem nas notas explicativas.

\section{Questão 9}

Após responder e analisar as oito questões do caso, os alunos deverão estar aptos a reconhecer três aspectos relevantes em relação às informações contábeis disponíveis nas empresas que realizam operações de decomposição ou análise. O primeiro é o caráter paradoxal das informações sobre os custos dos produtos individuais. Sem eles não há como se preparar as demonstrações financeiras. No entanto, como eles resultam de alocações necessariamente arbitrárias, não representam fidedignamente os custos de produção dos produtos. Isso indica que nem todas as informações divulgadas nas demonstrações financeiras são úteis nos termos do CPC 00 (R1).

O segundo aspecto é que a natureza das operações de decomposição obriga as empresas a fabricarem todos os produtos, ou não fabricar nenhum deles. Logo, a decisão de realizar a operação deve se fundamentar na comparação da receita total obtida com a venda de todos os produtos com os custos de produzi-los. A forma como os lucros individuais se distribuem é irrelevante. Isso foi devidamente evidenciado por meio dos custos apurados pelo método das unidades físicas de produção. Em dois casos, eles excederam as receitas auferidas com as vendas dos produtos, mas nenhum dos dois produtos deficitários poderia ser eliminado sem que o lucro total da Refinaria Fluminense S.A. diminuísse.

Finalmente, o terceiro aspecto é que, nas decisões de processar adicionalmente produtos individuais após o ponto de separação, os custos do processo conjunto são irrelevantes (sunk costs) porque já estão sendo incorridos. O que se quer saber é se haverá lucro no processamento adicional. Isso pode ser verificado pela comparação da receita incremental (receita na venda do produto após o processamento específico menos receita na venda do produto, tal como se encontra no ponto de separação) com o custo total incremental (o custo do processamento específico que será realizado). 